\title{
Pharmaceutical Storage Evaluation in Warehouse and Outlet of Apotek X Bantul Yogyakarta in 2018
}

\author{
Andy Eko Wibowo ${ }^{1, *}$ Widya Putri Lestari ${ }^{2}$
}

\author{
${ }^{1,2}$ Fakultas Kedokteran dan Ilmu Kesehatan Universitas Muhammadiyah Yogyakarta \\ *Corresponding author. Email: andyew@umy.ac.id
}

\begin{abstract}
The management of pharmaceutical preparations is a very important part of a pharmacy, because it is the main source of income, wrong or inefficient storage of drugs can cause drugs to expire, the number of dead stocks and drug rotation is not optimal. Errors in storage can make a drug become damaged / potential to be reduced and lead to treatments that are not optimal and effective. This study aims to evaluate the storage of pharmaceutical preparations in Apotek X based on Permenkes No. 73 of 2016 and determine whether or not there are indicators of storage of pharmaceutical preparations in warehouse and outlet of Apotek X in Bantul, Yogyakarta.

The design of this study was included in a non-experimental study, which was a descriptive design through direct observation and interviews. It was to describe the pharmaceutical preparation storage system in Apotek X whose results were compared with Permenkes No. 73 of 2016 and for indicator data used in this study were percentage calculation of expired / damaged drugs, dead stock, warehouse structuring system and inventory turnover (ITO).

Evaluation of pharmaceutical preparation storage in warehouse and outlet of Apotek X has not been in accordance with Republic of Indonesia Health Regulation No. 73 of 2016 concerning pharmaceutical service standards at pharmacies. The storage indicators are as follows: 1) Percentage of compatibility between goods and computer stock or card stock 98\% of 100\% preferably, 2) Inventory turnover in 2017-2018 with an average value of 10.18 times from 10-23 times preferably per year, 3) Percentage value of expired or damaged drugs $0.84 \%$ of preferably $<0.2 \%, 3$ ) Percentage of death stock $5,858 \%$ of preferably $0 \%$. These results indicate that the management of drugs is not entirely effective and efficient.
\end{abstract}

Keywords: drug management, pharmacy, and storage indicators

\section{INTRODUCTION}

Drugstore is a facility where pharmacy services are performed by a pharmacist. Based on Peraturan Menteri Kesehatan Republik Indonesia No. 73 of 2016, Apotek is a health service to promote better health for the people. ${ }^{1}$

Health services are all efforts made to always maintain and realize the achievement of health both in the context of preventing or curing diseases. ${ }^{2}$ One way to improve the quality of Apotek services as health service providers is to improve the efficiency and effectiveness of services with a logistical management system.

One of the logistics management handled by Apotek is pharmaceutical service. Pharmaceutical services are direct services to patients related to pharmaceutical preparations, namely drugs, traditional medicines, medicinal ingredients, and cosmetics in order to achieve definite results to improve patients' quality of life. ${ }^{3}$ One of the most important aspects in logistics management is the storage aspect of drug preparations.

Errors in drug storage can result in disadvantages, for example, patients experience drug poisoning as a result of taking expired or damaged drugs.
The objectives of this research are: to know the description of the suitability of storage of pharmaceutical preparations and medical devices in warehouse and outlet of Apotek X in Bantul, Yogyakarta in 2018 based on Permenkes RI No. 73 of 2016 , to know whether there are indicators or not, and to know how to minimize problems in terms of drug storage in pharmacy warehouses and Apotek outlets. ${ }^{1}$

\section{RESEARCH AND METHOD}

This research is a non-experimental descriptive study through observation, namely direct observation of the ongoing system in the implementation of pharmaceutical logistics storage management in warehouse and outlet of Apotek X, Bantul, Yogyakarta. This study compares the suitability referring to Peraturan Menteri Kesehatan Republik Indonesia No. 73 of 2016 concerning the standard of pharmaceutical services in pharmacies. ${ }^{1}$ Also, this research is to determine whether or not there are storage indicators of pharmaceutical preparations in the warehouse and outlets of Apotek X, Bantul Yogyakarta. 


\section{RESULTS AND DISCUSSION}

\subsection{Planning}

In planning, Apotek $\mathrm{X}$ uses the consumption method, through a software "Gampang Apotek". Gampang Apotek is a software for pharmacy management information system that is equipped with cashier sales features and inventory management. ${ }^{4}$

Steps in planning at Apotek X:

\subsubsection{Determine the average sales per day: amount of sales 3 months 90 days}

\subsubsection{Determine the minimum stock (1 week+ 4 days of lide time)}

11 times the average sales per day

\subsubsection{Determine the maximum stock (3 weeks) \\ 25 times the average sales per day \\ Order $=$ stock now - minimal stock amount ordered $=$ maximum stock - stock now}

\subsection{Procurement}

Drug procurement at pharmacy $\mathrm{X}$ is carried out twice a week, namely on Friday and Saturday. The procurement of data is taken from drug sales data for three months. Procurement of ordinary drugs through WhatsApp, while drugs classified as narcotics and psychotropic substances must include the content or active substance of these drugs.

\subsection{Reception}

The process of receiving pharmaceutical preparations and consumable medical materials at Pharmacy X is carried out in the outlet access hallway. Drug reception is carried out by warehouse staff and supervised by a CCTV to record all activities that occur in the receiving process. Furthermore, the warehouse staff will record in the invoice book, and ask for approval of the invoice that has been received to be signed by a pharmacist.

Reception of ordinary drugs and drugs classified as Narcotics, Psychotropics and Pharmacy Precursors is accepted and signed by the pharmacist. If the responsible pharmacist is not available, admission can be made by a pharmacist, medical or other health worker who has been authorized. $^{5}$

\subsection{Storage}

Storage is an activity to store and maintain by placing received drugs in a place deemed safe from theft as well as physical disturbances that can damage the quality of the drugs.
Drug administration standards at apotek $\mathrm{X}$ according Permenkes RI No. 73 of 2016 are shown in T 1.

Table 1. Drug administration standards at apotek $X$ according Permenkes RI No. 73 of 2016

\begin{tabular}{|l|c|c|}
\hline Components & Compatible & $\begin{array}{l}\text { Not } \\
\text { Compatible }\end{array}$ \\
\hline Dosage form & $\sqrt{ }$ & \\
\hline Therapy class & $\sqrt{ }$ & \\
\hline Alphabetical & $\sqrt{ }$ & $\sqrt{ }$ \\
\hline $\begin{array}{l}\text { FEFO (First } \\
\text { Expire First Out) }\end{array}$ & & $\sqrt{ }$ \\
\hline $\begin{array}{l}\text { FIFO (First In } \\
\text { First Out) }\end{array}$ & & \\
\hline
\end{tabular}

The arrangement of Pharmacy $\mathrm{X}$ warehouse uses three principles, namely based on dosage form, based on class of therapy and based on the Alphabetical system. This arrangement aims to ensure the quality of drugs is always guaranteed, avoid abuse, maintain continuity of supplies, and speed up the search ${ }^{5}$.

Based on comparison data with standards according to Permenkes No. 73 of 2016, the storage of pharmaceutical supplies at Apotek x showed 60\% results, which means that overall it has not met the standards or half of the standard data on the suitability of drug arrangement in the warehouse. Standard of storage requirement according Permenkes RI No.73 tahun 2016 are shown in Table 2.

Table 2. Standard of storage requirement according Permenkes RI No.73 tahun 2016

\begin{tabular}{|l|c|c|}
\hline \multicolumn{1}{|c|}{ Components } & Suit & Match \\
\hline Sanitation & - & $\sqrt{ }$ \\
\hline Temperature & $\sqrt{ }$ & - \\
\hline Moisture & $\sqrt{ }$ & - \\
\hline Ventilation & $\sqrt{ }$ & - \\
\hline Separation & - & $\sqrt{ }$ \\
\hline Pallet shelves/ cabinets & - & - \\
\hline Air Conditioner & $\sqrt{ }$ & - \\
\hline Refrigerator & $\sqrt{ }$ & - \\
\hline $\begin{array}{l}\text { Narcotics and } \\
\text { psychotropic cabinets }\end{array}$ & $\sqrt{ }$ \\
\hline Special wardrobe & $\sqrt{ }$ \\
\hline Thermometer & - & $\sqrt{ }$ \\
\hline Temperature card & - & \\
\hline Archive room & & \\
\hline $\begin{array}{l}\text { Percentage of storage requirements } \\
8 \\
\text { 13 x 100 } 61 \%\end{array}$ & & \\
\hline
\end{tabular}


From the data on the standard of storage requirement for pharmaceutical preparations, medical devices, and medical consumables according to Permenkes No.73 of 2016, Apotek $\mathrm{X}$ fulfilled $61 \%$ of the requirements that must be met in terms of drug storage.

Arrangement of pharmaceutical supplies in services are shown in figure 1.

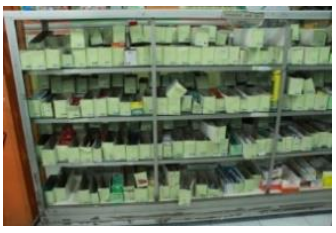

(a)

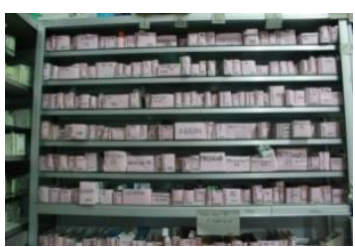

(c)

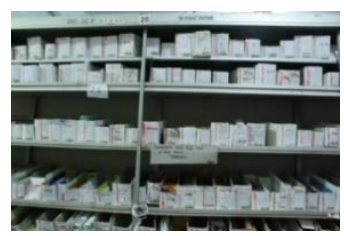

(b)

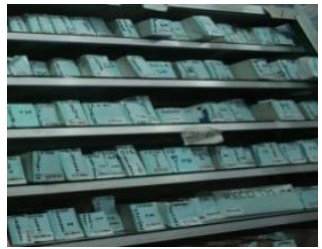

(d)
Figure 1. Service drug racks (a). Green box for generic drugs for syrup preparations and for tablets (b). White box for patent/branded drugs (over-the-counter drugs, limited-free drugs and hard drugs) (c). Pink box for ointment preparations (d). The upper blue box is for eye drops, and the bottom is for ear drops.

The purpose of coloring box is to minimize errors in taking and returning drugs and increasing service time. Meanwhile, for the service sector, the arrangement is classified based on the class of therapy and the placement of the medicines is arranged as attractive as possible by the way they are used. The front part is for medicinal drugs that are usually needed by other health workers such as midwives, doctors or nurses who usually collaborate with the x pharmacy. Service counter arrangement are shown in figure 2 .
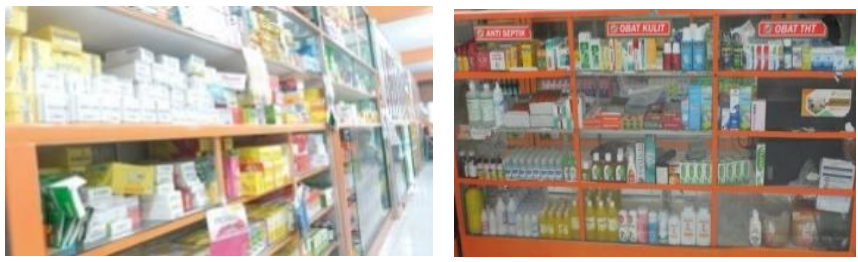

Figure 2. Service Counter Arrangement

\subsection{Extermination}

Extermination is an activity to settle unused pharmaceutical supplies due to expiration, damage, quality does not meet standards. However, Apotek X has never done extermination. The process of extermination for Apotek $\mathrm{X}$ is in collaboration with Bantul Puskesmas.

\subsection{Control}

Control aims to avoid shortages, excess, vacancies, damage, expiration, loss and return of orders. One way to control inventory at Apotek $\mathrm{x}$ is to use cashier SOP, the entry and exit of goods must be barcode-scaned. All boxes, both hard drugs and over-the-counter drugs, have a barcode attached. All transactions are made with a barcode system. If there are employees who do not use barcodes, there will be a punishment that correlates with a reduction in salary.

\subsection{Recording and reporting}

Recording is carried out in every process of managing pharmaceutical preparations, medical devices and consumable medical materials; starting from the receipt of incoming goods, invoice input, transfer from warehouse to outlet, to delivery of drugs (sales notes or receipts). For invoice storage, after being written in the book, the invoice is inputted to the computer and printed then sorted by the date of the invoice and stored on the medicine shelf in the warehouse.

\subsection{Evaluation of Storage Indicators}

\subsubsection{Percentage of conformity between goods} and computer's stock.

Percentage of conformity between goods and computer's stock are shown in Table 3.

Table 3. Percentage of conformity between goods and computer's stock.

\begin{tabular}{|l|l|}
\hline Concern & Quantity \\
\hline $\begin{array}{l}\text { Amount of appropriate fast-moving } \\
\text { drugs }\end{array}$ & 52 \\
\hline Total of types of fast-moving drugs & 53 \\
\hline Calculation $=\frac{\mathbf{5 2}}{\mathbf{5 3}} \boldsymbol{x} \mathbf{1 0 0}=\mathbf{9 8} \%$ & \\
\hline
\end{tabular}

The results of this study indicate the proportion of the amount of medicine on the computer stock card with the physical amount is $98 \%$. This shows that the accuracy of the warehouse clerk is quite good and thorough because it is almost $100 \%$ perfect. It was just that there was one drug that is not suitable because the drug has not been inputted but has to be removed so that the information on the electronic stock card was minus. 
According to WHO (2003) and Pudjaningsih (1996), the match between the drug stock card is good if it is $100 \%$ in accordance with stock card and physical medicine card. ${ }^{6}$

\subsubsection{Percentage value of expired or damaged drugs}

Expired drugs are one of the main indicators of the efficiency of drug storage in pharmaceutical warehouses. The number of expired drugs shows the amount of loss experienced by a pharmacy. ${ }^{7}$. Percentage of expired drugs are shown in Table 4.

Table 4. Percentage of Expired Drugs

\begin{tabular}{|l|l|l|}
\hline Concern & Quantity & Score \\
\hline Amount of Drug Expired & 47 & \multirow{2}{*}{$0,8 \%$} \\
\hline Total Types of Drugs & 5530 & \\
\cline { 1 - 1 } Calculation $=\frac{\mathbf{4 7}}{\mathbf{5 5 3 0}} \times \mathbf{1 0 0}=\mathbf{0 , 8 \%}$ \\
\hline
\end{tabular}

Results The percentage of expired drugs at Apotek X in 2018 was $0.8 \%$. It is estimated that the loss experienced is $\mathrm{Rp}$. $3,761,847$ rupiah during the period 2018. When compared to the standard made by Dwipudjaningsih (1996), that if the percentage of drug caddies and damage is less than 0.2 , it is still not appropriate. However, the presence of expired or damaged drugs from the warehouse or storage area was an indication of problems and losses in the case of incorrect drug storage.

Drug management to avoid damaged drugs or ED is as follows. ${ }^{8}$

a. Every receipt of drugs from PBF must be checked, both the condition and the expiration date. Drugs whose expiration date is less than two years should not be taken in.

b. For drugs with short ED, a list is made that contains the name and date of the drug so that it is easier to monitor

c. Medicines are stored with proper storage. Moist storage conditions can cause the packaging and even the drug to become damaged.

d. The choice of PBF that can exchange products that are close to ED is considered, so that drugs that are close to ED can be immediately exchanged to $\mathrm{PBF}$, or an agreement is made with PBF regarding the return of ED drugs.

e. Outlets implement the FEFO (First Expired First Out) storage system for drugs with EYD which is faster to issue first

f. Apotek management must always remember that defective drugs or ED are a disadvantage to the Apotek itself.

\subsubsection{Percentage of death stock}

The death stock according to the pharmacist of Apotek X is the drug supply that has not experienced movement for 3 months, or more, in the warehouse and the outlet fo Apotek $\mathrm{X}$. Percentage of death stock are shown in Table 5.

Table 5. Percentage of Death Stock

\begin{tabular}{|l|l|}
\hline Concern & Quantity \\
\hline Total death stock & 324 \\
\hline Total drugs & 5530 \\
\hline Calculation $=\frac{\mathbf{3 2 4}}{\mathbf{5 5 3 0}} \times \mathbf{1 0 0}=\mathbf{5 , 8 \%}$ \\
\hline
\end{tabular}

A high percentage of death stock indicates that the circulation of the drug supply was not smooth, causing these supplies to accumulate in warehouse and outlet. The buildup will have the potential to cause the drugs to soon-to-beexpired and be damaged. The results showed that the number of dead stock drugs was $5.858 \%$. These results are not efficient according to Pudjaningsih (1996) and Amirullah (2013), who said that the percentage of dead stock should be $0 \%$ or still be acceptable below $1 \%{ }^{3,9}$

Dead stock is usually caused by too many types of drugs available, and cases of disease that rarely use these drugs. This can be overcome in some ways:

a. Apotek must classify drugs including slow moving and fast moving before procurement.

b. Pharmaciests can offer death stock medicinal products to customers.

c. Apotek tries to sell the death stock as quickly as possible so that it does not pile up.

d. Pharmacy is better to order little by little, yet often, rather than to order in large quantities.

e. The pharmacy continues to pay attention to the stock card, then records drugs that are almost never sold for evaluation or consideration for next orders.

\subsubsection{Inventory Turnover}

Inventory turnover is a way to determine the efficiency level of Apotek inventory management. Inventory turnover parameter will show the ability of Apotek's funds embedded in the inventory to rotate within a certain period. ${ }^{10}$

If an Apotek has a high inventory turnover, it is considered healthy because of its good efficiency in managing existing supplies. The smaller of inventory turnover ratio, it's getting no better, likewise otherwise. ${ }^{11}$ In this study, to calculate inventory turnover, a comparison is made between the cost of goods sold and the average inventory. Inventory turnover value are shown in Table 6.

Table 6. Inventory Turnover Value

\begin{tabular}{|l|l|l|l|}
\hline Year & HPP & $\begin{array}{l}\text { Average } \\
\text { Inventory }\end{array}$ & Ratio \\
\hline 2017 & $6,473,650,042$ & $445,333,866$ & $13,18 \mathrm{x}$ \\
\hline 2018 & $7,629,909,972$ & $519,611,916$ & $13,29 \mathrm{x}$ \\
\hline
\end{tabular}


In 2017 and 2018, pharmacy X had an inventory turnover value of 13.18 and 13.29 respectively, which means that the funds invested in Apotek X rotated an average of 13 times in one year. According to Dwipunjaningsih (1996), the ideal inventory turnover value is 10 to 23 times a year.

Higher inventory turnover means more effective and efficient inventory management is carried out by the Apotek management to generate sales. However, the drug will run into a vacuum quicker, which must be balanced with a fast planning and procurement process. The factors that affect Inventory Turnover are as follows:
a. Supply demand
b. Lead time
c. Out of stock costs
d. Additional storage costs for supplies. ${ }^{12}$

\section{CONCLUSION}

Drug management at Apotek X, Bantul Yogyakarta in 2018 showed that the storage of pharmaceutical preparations at the warehouse of Apotek X was not in accordance with standards of permenkes RI No 73 tahun 2016. The storage indicator for the percentage of compatibility between goods and computer stock or card stock was $98 \%$, rather than $100 \%$. Inventory turnover for 2017-2018 was 13.18 and 13.29, respectively when it should have bee $10-23$ in one year. The percentage value of expired or damaged drugs was $0.84 \%$. This result is not in accordance with the standard according to Pudjaningsih (1996), which is $<0.2 \% .^{5}$ The percentage of dead stock was $5,858 \%$, not in accordance with the standard setting it to be $0 \%$.

\section{AUTHORS' CONTRIBUTIONS}

Concept and design; analysis and interpretation of data; critical revision of the paper for important intellectual content: Wibowo.

Acquisition of data; statistical analysis; drafting of the manuscript: Lestari.

\section{ACKNOWLEDGMENTS}

This research is supported by Universitas Muhammadiyah Yogyakarta.

\section{REFERENCES}

1. Permenkes RI number 73 Tahun 2016 about Pharmaceutical Service Standards at The Pharmacy. Jakarta : Menkes RI

2. Febriawati, Henni. Manajemen Logistik Farmasi Rumah Sakit. Yogyakarta: Gosyen. 2013

3. Suciati, S. Jurnal Manajemen Pelayanan Kesehatan Vol. 9. 2006. Page: 01.

4. Arief S, Sadiman, et al. Media Pendidikan. Jakarta: Raja Grapindo Persada. 2010.

5. Peraturan Badan Pengawas Obat dan Makanan RI Nomor 4 Tahun 2018 about Supervision, Management of Drugs, Drug Ingredients, Narcotics, Psychotropics, and Pharmacy Precursors in Pharmaceutical Service Facilities. Jakarta: BPOM.

6. Pudjaningsih. Tesis: Pengembangan Indikator Efisiensi Pengelolaan Obat di Farmasi Rumah Sakit, Yogyakarta : Magister Manajemen RS UGM. 1996

7. Peraturan Menteri Kesehatan Republik Indonesia Nomor 2052/MENKES/PER/X/2011 about Practice License and Implementation of Medical Practice. Jakarta: Depkes RI. 2011

8. Satibi, M. Rifqi, R., Hardika. Manajemen Apotek. Yogyakarta: Universitas Gadjah Mada.

9. Amirullah. 2013. Metodologi Penelitian Manajemen. Malang: Bayumedia. 2015

10. Riyanto, Agus. Aplikasi Metodologi Penelitian Kesehatan. Yogyakarta: Nuha Medika. 2009

11. Kasmir. Dasar-Dasar Perbankan. Jakarta: PT. Raja Grafindo Persada. 2012

12. Sudana. Manajemen Keuangan Perusahaan Teori dan Pabrik. Hal. 21. Jakarta: Erlangga. 2011 